\title{
REFERENCES TO HUMAN RIGHTS IN CODES OF ETHICS FOR PSYCHOLOGISTS: CRITICAL ISSUES AND RECOMMENDATIONS. PART II ${ }^{1}$
}

\author{
Janel Gauthier \\ School of Psychology \\ Laval University \\ 2325 rue des Bibliothèques, Quebec City, Quebec, G1V 0A6, Canada
}

\begin{abstract}
There are codes of ethics in psychology that explicitly refer to human rights. There are also psychologists interested in the protection and promotion of human rights who are calling for the explicit inclusion of references to human rights in all psychology ethics codes. Yet, references to human rights in ethics documents have rarely been the focus of attention in psychological ethics. This article represents the second part of a two-part article series focusing on critical issues associated with the inclusion of references to human rights in the ethical codes of psychologists, and recommendations about how psychological ethics and the human rights movement can work together in serving humanity. The first part of the article series examined issues pertaining to the interpretation of references to human rights in codes of ethics for psychologists, and the justifications for including these references in psychological ethics codes. The second part of the article series examines how the Universal Declaration of Ethical Principles for Psychologists can be used to extend or supplement codes of ethics in psychology, how ethical principles and human rights differ and complement each other, and how psychological ethics and the human rights movement can work together in serving humanity and improving the welfare of both persons and peoples.
\end{abstract}

Key words: codes, ethics, human rights, ethical principles, universal declarations, psychological ethics, globalization

\section{Introduction}

The first article in this two-part article series focused on critical issues associated with the inclusion of references to human rights in the ethical codes of psychologists. The article included an examination of the origin, historical development and contemporary meaning of human rights; an analysis of different approaches submitted in the literature to overcome the problem interpretation of human rights in ethics codes; and a consideration of the justifications for referring to human rights in psychological ethics codes. It was found that the concept of human rights is neither a unitary nor a universal construct, which creates difficulties for the interpretation of references to human rights in codes of ethics; that the approaches submitted to address the problem of interpretation have been

1 This article is based on an award address presented at the 75th Conference of the International Council of Psychologists in New York City, NY, 28-30 July 2017 and an invited keynote address presented at the First Pan-African Congress of Psychology in Durban, South Africa, 18-21 September 2017. 
unsatisfactory in terms of defining exactly what obligations references to human rights in psychology codes of ethics place on psychologists and to whom psychologists, as psychologists, owe them; and that there is no clear evidence indicating that references to human rights add to the theoretical basis or the guiding moral framework of codes.

Where does that leave us? Is there another more practical way to extend and supplement limitations in codes? The present article, the second in the two-part series, examines these questions along with others, and makes several recommendations about how psychological ethics and the movement of human rights can work together for the betterment of society and its members in an ever-globalizing world.

\section{The Universal Declaration of Ethical Principles for Psychologists}

If the drafters and reviewers of codes of ethics in psychology want to extend or supplement limitations in their codes, they can. There is an international ethics document describing ethical principles that they can refer to in their codes of ethics. It is called the Universal Declaration of Ethical Principles for Psychologists (2008). Adopted unanimously by the General Assembly of the International Union of Psychological Science and unanimously by the Board of Directors of the International Association of Applied Psychology in 2008 (Gauthier, 2008a, 2009; Ferrero \& Gauthier, 2009), this declaration is arguably the single most important international development in the history of psychological ethics. It was the outcome of a six-year process involving original research, broad international consultation, and numerous revisions of the framework and draft document in response to feedback and suggestions from the international psychology community (Gauthier, 2008b, 2008c; Gauthier \& Pettifor, 2011; Leach \& Gauthier, 2012).

The Universal Declaration of Ethical Principles for Psychologists (2008) was developed to provide a common moral framework and generic set of ethical principles to guide psychologists worldwide in meeting the ethical challenges of rapid globalization, a set of principles that encompasses all their scientific and professional activities as psychologists in a manner that also recognizes and may be used to address culture-specific interpretations. The moral framework presented in the Universal Declaration is defined in broad strokes that approach as close as possible (through much dialog and research) in reaching consensus on what can be globally acceptable. How should we treat others individually and collectively and how should we be treated? Research has shown great similarities among different cultures on humanitarian values (Gauthier, 2002; 2003; 2004; 2005; 2006; Gauthier \& Pettifor, 2011; 2012; Prentice, Dobson, \& Gauthier, 2017). It is the standards, behavioral rules and customs for their implementations that cause the greatest disagreement, along with the perception of outside interference that threatens one's cultural identity.

It is important to note that the Universal Declaration of Ethical Principles for Psychologists (2008) is not a worldwide code of ethics or code of conduct. Codes of conduct define what one must or must not do as a psychologist, whereas codes of ethics are more aspirational, and link standards to the overarching principles and values. A declaration of ethical principles reflects the moral principles and values that are expected to be addressed in a code of ethics or a code of conduct. 
The structure of the Universal Declaration of Ethical Principles for Psychologists (2008) consists of a preamble followed by four sections, each relating to a different ethical principle: Respect for the Dignity of Persons and Peoples; Competent Caring for Persons and Peoples; Integrity [in relationships]; and Professional and Scientific Responsibilities to Society. Each section includes a statement defining the principle and outlining ethical values contained in the principle. Both the ethical principles and the values contained in each principle are summarized in Table 1.

Table 1

Ethical Principles and Related Values Contained in the Universal Declaration of Ethical Principles for Psychologists (2008)

\begin{tabular}{|c|c|c|c|}
\hline $\begin{array}{c}\text { Principle I } \\
\text { Respect for the Dignity } \\
\text { of Persons and Peoples }\end{array}$ & $\begin{array}{c}\text { Principle II } \\
\text { Competent Caring for the } \\
\text { Well-Being of Persons and } \\
\text { Peoples }\end{array}$ & $\begin{array}{c}\text { Principle III } \\
\text { Integrity } \\
\text { (in Human Relations) }\end{array}$ & $\begin{array}{c}\text { Principle IV } \\
\text { Professional and Scientific } \\
\text { Responsibilities to Society }\end{array}$ \\
\hline $\begin{array}{l}\text { Values } \\
\text { - Respect for dignity and } \\
\text { worthiness of all human } \\
\text { beings } \\
\text { - Non-discrimination } \\
\text { - Informed consent } \\
\text { - Freedom of consent } \\
\text { - Privacy } \\
\text { - Protection of } \\
\text { confidentiality } \\
\text { - Fair treatment/Due } \\
\text { process }\end{array}$ & $\begin{array}{l}\text { Values } \\
\text { - Caring for health and well- } \\
\text { being } \\
\text { - Maximize benefits } \\
\text { - Minimize harm } \\
\text { - Offset/Correct harm } \\
\text { - Competence } \\
\text { - Self-knowledge }\end{array}$ & $\begin{array}{l}\text { Values } \\
\text { - Accuracy/Honesty } \\
\text { - Maximizing impartiality } \\
\text { - Minimizing biases } \\
\text { - Straightforwardness/ } \\
\text { Openness } \\
\text { - Avoidance of incomplete } \\
\text { disclosure } \\
\text { - Avoidance of conflict of } \\
\text { interest }\end{array}$ & $\begin{array}{l}\text { Values } \\
\text { - Development of } \\
\text { knowledge } \\
\text { - Use of knowledge for } \\
\text { benefits of society } \\
\text { - Avoid misuse of knowledge } \\
\text { - Promotion of ethical } \\
\text { awareness and sensitivity } \\
\text { - Promotion of highest } \\
\text { ethical ideals } \\
\text { - Ethical responsibilities to } \\
\text { society }\end{array}$ \\
\hline
\end{tabular}

The Universal Declaration of Ethical Principles for Psychologists (2008) articulates principles and values that are general and aspirational. It does not define any specific behavioral standards. It is stated in the preamble of the document that the application of the principles and values to the development of specific standards of conduct will vary across cultures and that it must occur locally or regionally to ensure their relevance to local or regional cultures, customs, beliefs, and laws. The Universal Declaration also claims to describe ethical principles that are "based on shared human values" (Preamble, 2008). Let it be noted that original research and broad international consultation were used to assess the universality of the ethical principles under consideration for inclusion the Universal Declaration (Gauthier, 2002; 2003; 2004; 2005; 2006; Gauthier \& Pettifor, 2011; 2012; Prentice, Dobson, \& Gauthier, 2017). Only those principles found to be the most universal were included in the moral framework used for drafting the declaration.

It is important to note that the Universal Declaration of Ethical Principles for Psychologists (2008) emphasizes respect and competent caring for individuals as well as for families, groups, and communities, with the aim of addressing the issue of balance between the individual and the communal, and allowing for appropriate differences across cultures in the interpretation, for example, of such ethical concerns as informed consent, confidentiality, privacy, professional boundaries, and ethical decision-making. The Universal Declaration of Ethical Principles for Psychologists, in its recognition of cultural diversity, is compatible with current developments in psychology to define multicultural competencies. So far, less than a handful of national codes of ethics have explicitly incorporated in their codes respect for the dignity of persons and peoples. Those codes 
are from Australia (Australian Psychological Society, 2007), Canada (Canadian Psychological Association, 2017), Guatemala (Colegio de Psicológos de Guatemala, 2011), and New Zealand (New Zealand Psychological Society, 2002).

There is no reference to human rights in the Universal Declaration of Ethical Principles for Psychologists (2008). This is not an oversight. The idea of referring the Universal Declaration of Human Rights (UDHR) (UN, 1948) in the document was carefully considered when the document was drafted. In the end, a decision was made to focus on the moral imperatives underlying human rights without using the term "human rights". Language was the issue:

"[...] the term 'human rights' has a negative connotation in some countries. In some parts of the world, human rights as defined in the UDHR (UN, 1948), are perceived as a political tool for harassing or controlling other nations, or as a lack of understanding and respect for different cultures, religions, or political systems. The use of the term 'human rights' in the Universal Declaration of Ethical Principles for Psychologists (2008) would have made it impossible for some countries to adopt and apply the declaration" (Gauthier \& Pettifor, 2012, p. 128).

That said, it is important to note that the Universal Declaration of Ethical Principles (2008) does not prevent any organization of psychology from including references to "human rights" into its code of ethics in any way it believes is beneficial. However, if an organization chooses not to include references to human rights in its code, it will find in the Universal Declaration of Ethical Principles a moral framework based on shared human values and a language that may be used to promote the same moral imperatives as those underlying human rights (e.g., primacy of respect for dignity, recognition of inherent worth of all human beings, non-discrimination, justice, freedom, well-being, privacy, consent, responsibilities to the community).

It is also worth noting that a "culture-sensitive" model has been developed to assist psychologists around the world in applying the Universal Declaration of Ethical Principles for Psychologists to create or review a code of ethics. Information about the model can be found in Gauthier, Pettifor and Ferrero (2010). In their article, the authors describe the steps involved in the application of the model and provides concrete examples as well as several useful comments and suggestions. The model has already been put to the test. It has been used by the College of Psychologists of Guatemala to develop its first code of ethics in 2009 and 2010 (Colegio de Psicológos de Guatemala, 2011). More recently, it has been used by the Canadian Psychological Association to revise its code (Canadian Psychological Association, 2017). Currently, it is being used by the Mexican Society of Psychology to revise its 2010 code (Sociedad Mexicana de Psicología, 2010).

\section{Ethical Principles and Human Rights: How Do They Differ and Complement Each Other?}

Let us now consider how the concept of ethical principles and the concept of human rights differ and complement each other and how they can work together in serving human kind. To answer these questions, we will compare the Universal Declaration of Ethical Principles for Psychologists (2008) and the UDHR (UN, 1948). The fundamental commonalities and differences between the two universal declarations are summarized in Table 2. 
The Universal Declaration of Human Rights (UN, 1948) and the Universal Declaration of Ethical Principles for Psychologists (2008): Commonalities and Differences

\begin{tabular}{|c|c|}
\hline \multicolumn{2}{|c|}{ COMMONALITIES } \\
\hline \multicolumn{2}{|c|}{ Both share the same fundamental goals of protecting society from harm and enhancing the quality of life. } \\
\hline \multicolumn{2}{|c|}{ Both were developed in response to the needs of their time. } \\
\hline \multicolumn{2}{|l|}{ Both recognizes the inherent dignity of all human beings. } \\
\hline \multicolumn{2}{|c|}{ Both rely on moral imperatives derived from the respect for the dignity of each human being. } \\
\hline \multicolumn{2}{|c|}{ Both support the highest standards of respect, liberty, equality and well-being of people. } \\
\hline \multicolumn{2}{|c|}{ DIFFERENCES } \\
\hline The Universal Declaration of Human Rights... & The Universal Declaration of Ethical Principles... \\
\hline $\begin{array}{l}\text { - addresses the responsibilities of governing states } \\
\text { and nations. }\end{array}$ & $\begin{array}{l}\text { - addresses the responsibilities of individual members } \\
\text { of a discipline. }\end{array}$ \\
\hline — is meant to be a firewall against state barbarism. & $\begin{array}{l}\text { - is meant to be a guide that inspires psychologists } \\
\text { worldwide toward the highest ethical ideals in their } \\
\text { activities. }\end{array}$ \\
\hline $\begin{array}{l}\text { - articulates standards that are specific, prescriptive } \\
\text { and legalistic in tone. }\end{array}$ & $\begin{array}{l}\text { - articulates principles and values that are general and } \\
\text { aspirational in tone. }\end{array}$ \\
\hline $\begin{array}{l}\text { - conceptualizes humanitarian values as legal rights, } \\
\text { moral entitlements. }\end{array}$ & $\begin{array}{l}\text { - conceptualizes humanitarian values as moral } \\
\text { principles and values. }\end{array}$ \\
\hline $\begin{array}{l}\text { - can be enforced through its ratification by } \\
\text { government of individual nations. }\end{array}$ & - has no mechanism of enforcement. \\
\hline $\begin{array}{l}\text { - is declared to consist of unalienable and inherent } \\
\text { natural rights that are beyond human intervention. }\end{array}$ & $\begin{array}{l}\text { - is declared to consist of ethical principles based on } \\
\text { human values shared across cultures. }\end{array}$ \\
\hline $\begin{array}{l}\text { - is considered absolute in applying to all human } \\
\text { beings everywhere at all times, without distinction of } \\
\text { any kind. }\end{array}$ & $\begin{array}{l}\text { - considers that the application of the ethical principles } \\
\text { and values to the development of specific standards } \\
\text { will vary across cultures. }\end{array}$ \\
\hline — Is considered never in need of review or revisions. & $\begin{array}{l}\text { - may be reviewed or revised to address new issues } \\
\text { or changing needs. }\end{array}$ \\
\hline $\begin{array}{l}\text { - describes rights aiming to protect members of the } \\
\text { human family as individuals. }\end{array}$ & $\begin{array}{l}\text { - describes ethical principles and values aiming to } \\
\text { protect members of the human family as individuals } \\
\text { (i.e., persons) and as groups or collectives (i.e., } \\
\text { peoples). }\end{array}$ \\
\hline $\begin{array}{l}\text { - considers that individual human rights are inalienable } \\
\text { (i.e., inherently inviolable) - the rights of the individual } \\
\text { have precedence over the rights of the communal. }\end{array}$ & $\begin{array}{l}\text { - recognizes the need to balance respect for the } \\
\text { individual and the communal (families, groups, } \\
\text { communities, peoples). }\end{array}$ \\
\hline
\end{tabular}

The Universal Declaration of Ethical Principles for Psychologists (2008) and the UDHR (UN, 1948) are each a product of their times. Although there is a span of 60 years in their creation, both share the same fundamental goals of protecting society from harm and enhancing the quality of life. Both are based on a general consensus of human thinking and discourse on what is morally right in addressing human problems. Both support the highest standards of respect, liberty, equality, and well-being of all peoples.

The Universal Declaration of Ethical Principles for Psychologists (2008) reflects a concern that psychologists in a rapidly globalizing world need ethical guidelines that address global issues and can encompass working cooperatively across worldviews in ways that were not included in their professional training, their practice standards, their codes of ethics, or their past experiences. The larger context is the desire that the rapid globalization of life on the planet contributes to a better life for persons and peoples generally, rather than contributes to increased suffering. While technology makes possible "one world", the needs of people to maintain their cultural identities demand respect and, in addition, negate rules and prescriptions imposed from the outside on how they should conduct 
their lives. In this context, guidance from a moral framework that approaches universality leaves room for local initiative in defining culture-specific interpretations. The Universal Declaration of Ethical Principles for Psychologists supports globalization that is "enlightened" (i.e., based on sharing and respect for cultural differences and commonalities), and is not "unilateral" (i.e., imposed to serve political and economic interests of a few to the detriment of the others). It addresses relationships of psychologists as psychologists, and emphasizes respect and caring for individuals, families, groups, and communities, as well as respecting cultural differences that do not violate its moral framework.

The UDHR (UN, 1948) was developed by the UN to ensure that state-sponsored horrific acts of cruelty and racism such as those that occurred under the Nazi regime would never happen again in the world. The document proclaims that all human beings have unalienable rights and entitlements to freedom and dignity, to be free of specified harms, and to enjoy the benefits of society equally with others. The rights are specific and the same for all societies and do not vary with different political, religious, or cultural entities. The UDHR is directed primarily at all nations and states to ensure freedom and justice for its citizens, and to protect them from oppression and harm. There continue to be grave violations of human rights in many parts of world today, and in many countries, work involving the UDHR is highly valued.

Both universal declarations share the fundamental goals of protecting society from harm and the enhancement of the quality of life of its members. Both rely on respect for human life and human dignity. However, as shown in Table 2, there are important differences between these two declarations. For example, the ethics document addresses individual members of a discipline and a discipline as whole, while the human rights document addresses the responsibilities of nations. The ethics document has no mechanisms of enforcement, whereas human rights documents may be implemented and enforced through their ratification by the government of individual nations - when a State ratifies a particular declaration or treaty, it signifies that it agrees to be legally bound by the terms of that declaration or treaty. The ethics document recognizes that the ways the ethical principles and values are expressed must be determined locally or regionally to ensure their relevance to local or regional cultures, customs, beliefs, and laws, whereas the UDHR is considered absolute in applying to all human beings without distinction of any kind at all time. The ethics document considers as important that all communities and cultures adhere to moral values that respect their members both as individual persons and as collective peoples, whereas the UDHR ascribes rights aiming to protect members of the human family only as individual persons - in 2007, the UN adopted a declaration on the rights of indigenous peoples to establish a framework of minimum standards for the survival, dignity and well-being of the indigenous peoples of the world (UN, 2007), but the UN has yet to address the rights of non-indigenous peoples. Unlike the ethics document, the UDHR is considered by the UN to be never in need of revisions - to address certain rights that were not addressed specifically in the 1948 document, the $\mathrm{UN}$ has adopted covenants, conventions and other human rights documents instead of amending the UDHR. Despite these differences, there is a high level of congruence between the ethical principles and values described in the Universal Declaration of Ethical Principles for Psychologists and the fundamental human rights set out in the UDHR, as shown in Table 3. The language in each document may be different, but the moral imperatives underlying both documents are quite similar. 
Connecting Human Rights and Ethics: Similarities in humanitarian values but differences in language

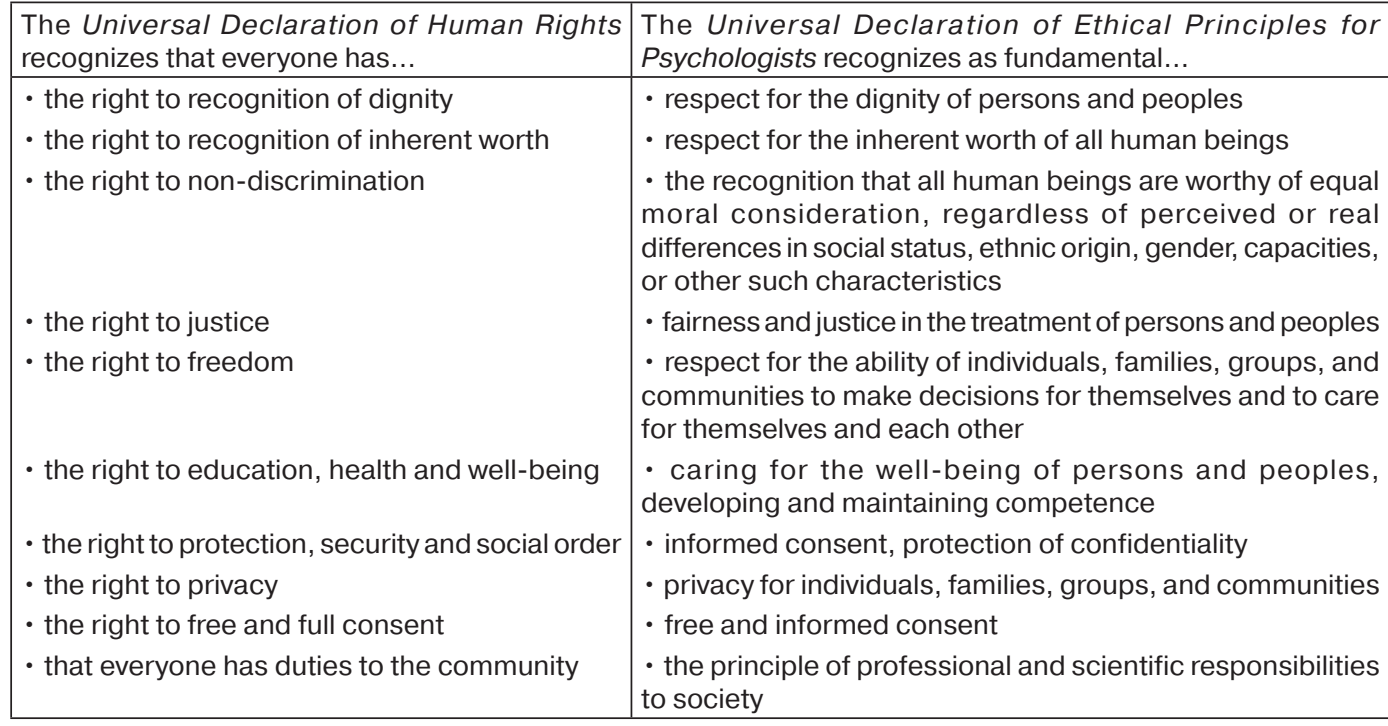

What authority is there for accepting the human rights and the ethical principles as described in these two universal declarations?

The historical antecedents of the UDHR (UN, 1948) included the Ten Commandments and other religious documents from ancient times believed to be received directly from the Creator or God. Revolutions in the 17th and 18th centuries invoked the concept of natural law or God's natural law, thus maintaining a powerful supernatural authority. Today, the UDHR is declared to consist of unalienable and inherent natural rights that are beyond human intervention, even though the UDHR itself was created with wide consultation by a UN Commission on Human Rights. Today, God, by whatever name, is less frequently mentioned, but the divine authority over humankind appears to be implicit in the UDHR.

The authority for the Universal Declaration of Ethical Principles for Psychologists (2008) lies in a consensus on the nature of ethical principles. As mentioned earlier in this article, research was conducted and broad international consultation were used to identify human values that are shared across cultures. The research conducted to identify those values yielded data showing that the generic set of ethical principles that provided the moral framework for drafting the document was based on shared human values. The Universal Declaration of Ethical Principles describes ethical principles that are truly based on shared human values, as demonstrated through research and broad international consultation. Those ethical principles are defined in broad strokes that approach as close as possible (through research and much dialog) in reaching consensus on what ca be universally acceptable.

As indicated in Table 2, a major difference between the two declarations is that the UDHR (UN, 1948) is primarily for nations and the Universal Declaration of Ethical Principles for Psychologists (2008) for members of the psychological community. That said, human rights agendas that target primarily nations and governments, and universal 
ethical principles that guide professional associations and their members, are both required in achieving a better life for the inhabitants of a global world. The UDHR names serious abuses of human rights, from which everyone should be free, and the elimination of which few could disagree, such as torture, slavery, arbitrary arrest, and persecution. Promoting positive rights both locally and globally is also important, such as ensuring standards of living, social security, social services, opportunities for education and work, and so on. Both are required in achieving a better life for the inhabitants of a global world. Both have a role to play. The effectiveness of each declaration in building a better world may be greater because their roles complement each other, but are not the same.

\section{Psychology and Human Rights}

As previously demonstrated in this two-part article series, it is unclear what source psychologists should use when interpreting references to human rights in codes of ethics. In the absence of a clear definition of human rights in a code, the most feasible interpretation is that they should consult international human rights law. This is problematic, however, because the imprecise nature and complexity of human rights law and its prescriptive nature introduce a level of uncertainty that should be avoided in codes of ethics, especially if such references are not well integrated into or do not add to codes' theoretical basis and guiding moral framework.

That said, one ought to recognize that the $\operatorname{UDHR}(\mathrm{UN}, 1948)$ is a milestone document in the history of human rights. It has been, and continues to be, influential in moving countries to respect the dignity inherent in every person as a human being. Other declarations of human rights have been developed outside of the UN. These declarations reaffirm individual human rights, but they also proclaim the right of nations to freedom and self-determination, their right to preserve their independent identity, their right to free themselves from the bonds of foreign domination, and their right to take into account their cultural and religious context when interpreting, promoting and protecting human rights. None of these declarations is perfect. All of them have limitations. Still, all of them play an important role in building a better world. Does the lack of perfection matter if the declarations work for the betterment of individuals and societies?

Psychology functions as a discipline within the context of human society. As a science and a profession, it has responsibilities to society. These responsibilities, as described in the Universal Declaration of Ethical Principles for Psychologists (2008), include among other things "conducting its affairs within society in accordance with the highest ethical standards, and encouraging the development of social structures and policies that benefit all persons and peoples" (Principle IV - Professional and Scientific Responsibilities to Society: 36$)$. Does psychology have responsibilities to society regarding the promotion and protection of human rights? If so, what does it mean for psychology and for psychologists?

Some psychologists (e.g., Hagenaars, 2016a; Seymour \& Nairn, 2012) think that psychology has the duty to play a more active role in the promotion and defence of human rights. Some organizations of psychology think the same. The European Federation of Psychologists' Associations (EFPA), for example, has created a Board on Human Rights 
and Psychology in 2015 "to raise awareness among psychologists of human rights and (risks of) human rights violations, to prevent human rights violations, and alleviate the effects of human rights violations" (EFPA, 2017, p. 2). Any activity or action that can help to establish human dignity for all persons and peoples is welcome and warrants serious consideration.

Various actions have been proposed to raise the awareness of human rights among psychologists. One of them has been to include references to human rights into all codes of ethics for psychologists (e.g., Hagenaars, 2016a). However, as demonstrated in the first part of this two-part article series, it cannot be recommended because of the issues it raises. Another one has been to incorporate human rights education in the continuous professional development and the education and training of psychologists (Hagenaars, 2016b). Let us consider why this later idea is worth pursuing and how it could be applied to be as appropriate and meaningful as possible.

Human rights law has been, and remains, influential in moving nations to respect the dignity of all members of the human family. Psychologists have an important responsibility and role to play in promoting the most fundamental values required to establish human dignity for all persons and peoples. This is not to say that all psychologists should be human rights activists. However, all psychologists should have knowledge and understanding of the body of international law designed to promote human rights. They should know how to reconcile real or apparent conflicts between what is permissible under the law in the country where they live or work, their codes of ethics, and the various instruments of international human rights law.

Some of the UN human rights documents are of specific importance for psychologists acting in their professional capacities. For example, psychologists working with persons with disabilities should know about the Convention on the Rights of Persons with Disabilities (UN, 2006); those working with persons with developmental disabilities should know about the Declaration on the Rights of Mentally Retarded People (UN, 1971); those working with children should have a good knowledge of the Convention of the Rights of the Child (UN, 1989); those working with indigenous peoples should be aware of the Declaration on the Rights of Indigenous Peoples (UN, 2007); those working with refugees should be familiar with the Convention Relating to the Status of Refugees (UN, 1951); psychologists working with victims of torture and other cruel, inhuman or degrading treatment should be familiar with the Convention against Torture and Other Cruel, Inhuman or Degrading Treatment or Punishment (UN, 1984). However, in addition to being knowledgeable about the various $\mathrm{UN}$ human rights instruments, psychologists should also be knowledgeable about the ones developed outside of the $\mathrm{UN}$ and which for whatever reason have not been ratified by the UN. In a globalizing world, it is imperative that psychologists be well and fully informed about how human rights are defined and conceptualized around the world and why such differences exist.

It is recognized in the Universal Declaration of Ethical Principles for Psychologists (2008) that differences exist in the way professional and scientific responsibilities to society are interpreted by psychologists in different cultures and that they need to be considered in a way that is culturally appropriate and consistent with the ethical principles and related values of the Declaration. As previously demonstrated, the construct of human rights is 
neither unitary nor universal. Differences exist in the way human rights are articulated and interpreted in different cultures and they need to be considered in a way that is culturally appropriate. Because it is based on shared human values, the Universal Declaration of Ethical Principles for Psychologists can provide psychologists with a useful moral framework to address culture-specific interpretations of human rights in a way that is both culturally appropriate and ethically sound.

\section{Ethical Principles and Human Rights in a Globalizing World: Working Together in Serving Humanity}

Globalization is with us and will continue to grow exponentially. Will it be "unilateral" or "enlightened" (Kim \& Park, 2007)? Enlightened globalization is based on understanding, dialogue, respect and integrating knowledge to foster cultural development. It recognizes that each culture has its own set of values, beliefs, practices, and resources that integrate diverse information to transform the world. Unilateral globalization is based on the belief that one's own culture and values are superior to others and the imposition of one's own culture and values on others. It violates all concepts of virtue, ethics and human rights, and constitutes a form of oppression. Enlightened globalization may lead to greater harmony, while unilateral globalization by dominant cultures will not (Pettifor \& Ferrero, 2012). Some countries allege that today's Western societies have been and continue to be guilty of "moral imperialism". The need is urgent today for awareness of the impact of globalization, and collaboration is essential if globalization is to be "enlightened" rather than "unilateral and oppressive".

Globalization must be enlightened to be ethical. To be enlightened, globalization must be respectful, fair, and beneficial across nations and cultures. How can we bring different people from different cultures together to create a better world? How can professional ethics and human rights work together in serving humanity? How can they be seen as universally respectful rather than unilaterally imposed? Authors addressing those questions (e.g., Pettifor \& Ferrero, 2012) recommend prolonged dialogue, open discussion of virtue, ethics and human rights issues, building trust and understanding of cultural and political issues; generally avoiding confrontations, coercion and hostile encounters. The recommendations reflect the belief that common humanitarian values exist across cultures, and that human rights legislation and codes of ethics cannot be enforced on those who perceive them to be a threat to their cultural identity. To achieve globalization that is positive for all persons and peoples, we need to focus on shared human values. We also need to be sensitive to and respectful of differences in cultures, values, beliefs, customs, history, worldviews, and laws. Prescriptive/imposed approaches lead to resistance; aspirational/educational approaches allow learning, understanding, evolution.

There are no maps showing the way to enlightened globalization. However, the UDHR (UN, 1948) has charted the rights and entitlements of all human beings, and named abuses that must be eliminated (largely by governments). The Universal Declaration of Ethical Principles for Psychologists (2008) provides a moral framework and a generic set of ethical principles to guide psychologists worldwide in maintaining common human values while also honoring and understanding culture-specific differences. Work continues within the profession on developing multicultural competencies that not only respect and honor differences in cultural beliefs and practices, but also help to resolve dilemmas 
imposed by a perceived clash of cultures (Gielen, Draguns, \& Fish, 2008; Pettifor \& Ferrero, 2012).

Globalization increases the need for psychologists to accept an active role in changing the conditions in society that contribute to the suffering and dehumanization of persons and peoples. Most psychology codes of ethics include responsibility to society and a commitment to work in respectful ways to change those aspects of society that pose serious violations of their ethical principles. Many codes fall short of using the language of social justice. Violations of human rights often may be considered acts of social injustice, and therefore social justice and human rights issues become similar. Psychology, ethics and human rights have much to contribute and much to share in a globalizing world.

The debate between extreme universalism and extreme cultural relativism is nonproductive. It is possible to maintain independent moral standards, as in the UDHR (2008), as well as apply moral principles, as in the Universal Declaration of Ethical Principles for Psychologists (UN, 1948), with respect for both cultural differences and social political contexts. To do so requires mutual respect, dialogue, listening, understanding, collaboration, and mutual sense of purpose.

\section{Conclusion}

In conclusion, references to human rights in codes of ethics for psychologists raise critical issues. First, the concept of human rights is neither a unitary nor a universal construct. It has evolved and become more inclusive over time, but it has not achieved "universality". The absence of a universally acceptable definition of human rights creates difficulties for the explicit inclusion of references to human rights in all psychology codes of ethics around the world, as requested by some psychologists wishing psychology to play a more active role in the protection and promotion of human rights. Second, most references to human rights in psychology codes of ethics are made without providing psychologists with the information needed to interpret those differences. Furthermore, wherever a definition is provided, it is not clear exactly what obligations this places on psychologists and to whom psychologists, as psychologists, owe them. Third, there is no clear indication that references to human rights in psychology codes of ethics add to the theoretical basis or the guiding moral framework of codes.

Where does that leave us? Given the situation, is it preferable not to refer to human rights in codes of ethics? Yes and no. It depends on the context and the information provided. There could be many good reasons for an organization to include references to human rights in its code. For example, an organization may want to raise awareness of human rights among its members or demonstrate its commitment to the protection and promotion of human rights. Nothing prevents an organization of psychology from including references to "human rights" in its code of ethics in any way it believes is beneficial. However, if an organization of psychology chooses to include references to human rights in its code, it should also provide in it all the information needed to facilitate the interpretation of those references by psychologists and the understanding of the obligations this places on them and to whom they owe them.

In comparison with references to human rights, the Universal Declaration of Ethical Principles for Psychologists (2008) offers a more practical and effective way to supplement 
and strengthen ethical codes. Not only does it describe ethical principles based on shared human values across cultures; it also provides a moral framework to encourage global thinking about ethics, while encouraging action that is sensitive and responsive to local needs and values. In addition, it provides a language that can inspire psychologists toward the highest ethical ideals in their professional and scientific work.

The UDHR (UN, 1948) is a milestone in the history of human interactions and the cause of human rights. It has been, and continues to be, influential in moving nations to respect the dignity inherent in all human beings. Does psychology have responsibilities to society regarding the promotion and protection of human rights? Psychology functions as a discipline within the context of human society. As a science and a profession, it has responsibilities to society. Differences exist in the way these responsibilities are interpreted by psychologists in different cultures. While acknowledging those differences, psychology should ensure that psychologists have adequate knowledge of human rights and that they are trained in ethical decision-making to address real or apparent conflicts between what is permissible under their codes of ethics, the law in the country where they live or work, and human rights law.

Ethical principles and human rights strengthen and complement each other. In ethics, we envision a free, just, and peaceful world in accordance with the highest humanitarian values of our existence. In human rights, we envision a free, just, and peaceful world where abuses and injustices are eliminated. However, there are important differences between ethics and human rights. Each has its own language, history, culture, method, approach, and agenda. Despite those differences, they can be good companions and work together in serving humanity. What is required to ensure a successful cooperation between ethics and human rights is mutual respect, open discussion, mutual understanding, commitment, and mutual sense of purpose.

Both ethics and human rights are needed to achieve enlightened globalization. There is much room for listening and dialogue on the road to global understanding and harmony.

\section{REFERENCES}

Australian Psychological Society (2007). APS code of ethics. Melbourne, Australia: Author.

Canadian Psychological Association. (2017). Canadian code of ethics for psychologists (4th ed.). Ottawa: Author.

Colegio de Psicológos de Guatemala. (2011). Código de Ética [Code of Ethics]. Ciudad de Guatemala: Servisa Litografía.

European Federation of Psychologists' Associations. (2017). Report 2015-2017 of the EFPA Board on Human Rights and Psychology to the EFPA General Assembly in Amsterdam on July 15-16, 2017. Retrieved from the European Federation of Psychologists' Associations website: http://www.efpa. eu/reports/reports-general-assembly-2017

Ferrero, A., \& Gauthier, J. (2009). Desarrollo y adopción de la Declaración Universal de principios Éticos para Psicólogas y Psicólogos [The development and adoption of the Universal Declaration of Ethical Principles for Psychologists]. Boletín de la SIP, 90 (March), 8-10. Retrieved from http:// issuu.com/sipsych/docs/sip_newsletter_v90_march_2009

Gauthier, J. (2002). Ethics and human rights: Toward a universal declaration of ethical principles for psychologists. In J.L. Pettifor (Chair), Professional codes of ethics across national boundaries: Seeking 
common grounds. Symposium conducted at the 25th International Congress of Applied Psychology, Singapore.

Gauthier, J. (2003). Toward a universal declaration of ethical principles for psychologists. In J.B. Overmier \& J.A. Overmier (Eds.). Psychology: IUPsyS Global Resource [Computer software] (4th ed.). Hove, UK: Psychology Press.

Gauthier, J. (2004). Toward a universal declaration of ethical principles for psychologists. International Association of Applied Psychology/Newsletter, 16(4), 10-24.

Gauthier, J. (2005). Toward a universal declaration of ethical principles for psychologists: A progress report. In M.J. Stevens \& D. Wedding (Eds.), Psychology: IUPsyS global resource [Computer software] (6th ed.). Hove, UK: Psychology Press.

Gauthier, J. (2006). Onward toward a universal declaration of ethical principles for psychologists: Draft and progress report. In M.J. Stevens \& D. Wedding (Eds.), Psychology: IUPsyS global resource [Computer software] (7th ed.). Hove, UK: Psychology Press.

Gauthier, J. (2008a). IAAP adopts the universal declaration of ethical principles for psychologists. The IAAP Bulletin: The International Association of Applied Psychology, 20(4), 110-112.

Gauthier, J. (2008b). The universal declaration of ethical principles for psychologists presented at the United Nations DPI/NGO conference in Paris. Psychology International, 19(4), n.d. Retrieved from http://www.apa.org/international/pi/2008/10/gauthier.aspx

Gauthier, J. (2008c). Universal declaration of ethical principles for psychologists. In J. Hall \& E. Altmaier (Eds.), Global promise: Quality assurance and accountability in professional psychology (pp. 98-109). London: Oxford University Press.

Gauthier, J. (2009). Ethical principles and human rights: Building a better world globally. Counselling Psychology Quarterly, 22, 25-32.

Gauthier, J., \& Pettifor, J. (2011). The evolution of ethics in psychology: Going international and global. In P.R. Martin, F. Cheung, M. Kyrios, L. Littlefield, M. Knowles, B. Overmier, \& J.M. Prieto (Eds.), The IAAP handbook of applied psychology (pp. 700-714). Oxford, UK: Blackwell Publishing.

Gauthier, J., \& Pettifor, J.L. (2012). The tale of two universal declarations: Ethics and human rights. In M.M. Leach, M.J. Stevens, G. Lindsay, A. Ferrero, \& Y. Korkut (Eds.). The Oxford Handbook of International Psychological Ethics (pp. 113-133). Oxford, England: Blackwell Publishing.

Gauthier, J., Pettifor, J., \& Ferrero, A. (2010). The universal declaration of ethical principles for psychologists: A culture-sensitive model for creating and reviewing a code of ethics. Ethics and Behavior, 20(3\&4), 1-18.

Gielen, U., Draguns, J., \& Fish, J. (Eds.). (2008). Principles of multicultural counseling and therapy. New York: Routledge/Taylor and Francis Group.

Glendon, M.A. (2001). A world made new: Eleanor Roosevelt and the Universal Declaration of Human Rights. New York, NY: Random House.

Hagenaars, P. (2016a). Towards a human rights based and oriented psychology. Psychology and Developing Societies, 28(2), 183-202.

Hagenaars, P. (2016b). Ingredients for human rights education of psychologists. In Human rights education for psychologists and fundamental rights awareness experts' meeting abstracts - Venice, 9-11October 2016 (pp. 18-19). Retrieved from European Federation of Psychologists' Associations website: http://human-rights.efpa.eu/information/

Kim, U., \& Park, Y-S. (2007). Development of indigenous psychologies: Understanding people in a global context. In M.J. Stevens \& U.P. Gielen (Eds.), Toward a global psychology: Theory, research, intervention, and pedagogy (pp. 147-172). Mahwah, J.J.: Erlbaum. 
Leach, M.M., \& Gauthier, J. (2012). Internationalizing the professional ethics curriculum. In F.T.L. Leong, W. Pickren, M.M. Leach, \& A.J. Marsella (Eds.), Internationalizing the psychology curriculum in the United States: Meeting the challenges of globalization (pp. 29-50). New York: Springer Publications.

New Zealand Psychological Society. (2002). Code of ethics for psychologists working in Aotearoa/New Zealand. Wellington: Author.

Pettifor, J.L., \& Ferrero, A. (2012). Ethical dilemmas, cultural differences, and the globalization of psychology. In M.M. Leach, M.J. Stevens, G. Lindsay, A. Ferrero, \& Y. Korkut (Eds.). The Oxford Handbook of International Psychological Ethics (pp. 28-41). Oxford, England: Blackwell Publishing.

Prentice, J., Dobson, K., \& Gauthier, J. (2017). Ethics from a global perspective. In S.G. Hofmann (Ed.). International Perspectives on Psychotherapy (p. 241-257). New York: Springer International.

Seymour, F., \& Nairn. R. (2012). Aotearoa/New Zealand. In M.M. Leach, M.J. Stevens, G. Lindsay, A. Ferrero, \& Y. Korkut (Eds.). The Oxford Handbook of International Psychological Ethics (pp. 405423). Oxford, England: Blackwell Publishing.

Sociedad Mexicana de Psicología. (2010). Código ético del psicólogo [The psychologist's code of ethics] (5th ed.). Mexico: Editorial Trillas.

United Nations. (1948). Universal declaration of human rights. Retrieved from http://www.un.org/en/ universal-declaration-human-rights/

United Nations. (1951). Convention relating to the status of refugees. Retrieved from http://www.unhcr. org/1951-refugee-convention.html

United Nations. (1971). Declaration on the rights of mentally retarded people. Retrieved from http:// www.ohchr.org/EN/ProfessionalInterest/Pages/RightsOfMentallyRetardedPersons.aspx

United Nations. (1984). Convention against Torture and Other Cruel, Inhuman or Degrading Treatment or Punishment. Retrieved from http://www.ohchr.org/EN/ProfessionalInterest/Pages/CAT.aspx

United Nations. (1989). Convention on the rights of the child. Retrieved from http://www.ohchr.org/ EN/ProfessionalInterest/Pages/CRC.aspx

United Nations (2006). Convention on the rights of persons with disabilities. Retrieved from http://www. ohchr.org/EN/HRBodies/CRPD/Pages/ConventionRightsPersonsWithDisabilities.aspx

United Nations (2007). Declaration on the Rights of Indigenous Peoples. Retrieved from https://www. un.org/development/desa/indigenouspeoples/declaration-on-the-rights-of-indigenous-peoples. html

Universal Declaration of Ethical Principles for Psychologists. (2008). Retrieved from http://www.iupsys. net/about/governance/universal-declaration-of-ethical-principles-for-psychologists.html

(C) Gauthier J., 2018

\author{
Article history: \\ Received 15 February 2018 \\ Revised 15 April 2018 \\ Accepted 17 April 2018
}

\title{
For citation:
}

Gauthier, J. (2018). References to Human Rights in Codes of Ethics for Psychologists: Critical Issues and Recommendations. Part II. RUDN Journal of Psychology and Pedagogics, 15(2), 131146. doi: 10.22363/2313-1683-2018-15-2-131-146 


\title{
Bio Note:
}

Janel Gauthier - Ph.D., Professor Emeritus at the School of Psychology of Laval University in Quebec City, Canada, and President of the International Association of Applied Psychology. Since 2002, ethics and human rights are the main focus of his research and publications. He has received numerous awards for his distinguished contributions to the international advancement of psychological ethics. He was the Chair of the international working group that developed the Universal Declaration of Ethical Principles for Psychologists. Scopus ID: 7202654309. E-mail: janel. gauthier@psy.ulaval.ca

\section{ОТРАЖЕНИЕ ПРАВ ЧЕЛОВЕКА В ЭТИЧЕСКИХ КОДЕКСАХ ПСИХОЛОГОВ: КРИТИЧЕСКИЕ ЗАМЕЧАНИЯ И РЕКОМЕНДАЦИИ. ЧАСТЬ II}

\author{
Жанель Готье \\ Университет Лаваля \\ Рю де Библиотек, 2325, Квебек, Квебек G1V 0A6, Канада
}

\begin{abstract}
В психологии существуют этические кодексы, которые напрямую соотносятся с правами человека. В тоже время есть ряд психологов, заинтересованных в защите и поддержании прав человека, которые призывают к включению прямых ссылок на права человека во все психологические этические кодексы. Однако в психологической этике редко уделяется большое внимание вопросам ссылок на права человека в этических документах.

Данная статья представляет собой вторую часть серии статей, посвященных полемическим вопросам, связанным с включением прямых ссылок на права человека в этические кодексы психологов, а также возможным рекомендациям о том, как психологическая этика и правозащитное движение могут работать вместе в служении человечеству.

В первой части серии статей были рассмотрены вопросы относительно интерпретации отражения прав человека в этических кодексах психологов, а также обоснования включения непосредственных ссылок на права человека в эти кодексы. В данной статье рассматривается как «Универсальная декларация этических принципов для психологов» может быть использована для расширения или дополнения этических кодексов в психологии; каким образом отличаются этические принципы и права человека и как они дополняют друг друга; а также как совместное продвижение психологической этики и прав человека может способствовать улучшению благосостояния как отдельных людей, так и народов.
\end{abstract}

Ключевые слова: кодексы, этика, права человека, этические принципы, «Универсальная декларация этических принципов для психологов», психологическая этика, глобализация

(C) Готье Ж., 2018

\author{
История статьи: \\ Поступила в редакцию: 15 февраля 2018 \\ Принята к печати: 17 апреля 2018
}




\section{Для цитирования:}

Готье Ж. Отражение прав человека в этических кодексах психологов: критические замечания и рекомендации. Ч. II // Вестник Российского университета дружбы народов. Серия: Психология и педагогика. 2018. Т. 15. № 2. С. 131-146. doi: 10.22363/2313-1683-201815-2-131-146

\section{Сведения об авторе:}

Жанель Готье - Ph.D., почетный профессор Школы психологии Университета Лаваля (Квебек, Канада), президент Международной ассоциации прикладной психологии. С 2002 года этика и права человека являются основными направлениями его исследований и публикаций. Он получил многочисленные награды за выдающийся вклад в международное продвижение психологической этики. Он был председателем международной рабочей группы, которая разработала «Универсальную декларацию этических принципов для психологов». Scopus ID: 7202654309. E-mail: janel.gauthier@psy.ulaval.ca 